\title{
Over-the-top and under the radar
}

\author{
An analysis of Internet distribution \\ and its structural consequences in Denmark
}

\section{Sofie Flensburg}

Department of Communication, University of Copenhagen, Denmark

\begin{abstract}
The article traces the evolution of over-the-top (OTT) services in order to analyse how the growing use of Internet distribution influences the structural conditions and institutional arrangements in Denmark. This story is told in four parts: first, I outline how the shift from postal services to e-mail restructured the conditions for asynchronous one-to-one communication; second, I examine the introduction of web-based services and the declining role of the press as gatekeeper for asynchronous one-to-many communication; third, I focus on the impact of mobile broadband and smartphones on synchronous one-to-one communication and the telecommunications sector; and fourth, I analyse the emergence of streaming technologies and the reorganisation of synchronous one-to-many communication and broadcasting. Building on these examples, I argue that key welfare state principles have come under pressure and that research tends to underestimate the fundamental transformations of the institutional order.
\end{abstract}

Keywords: OTT, digital distribution, Internet infrastructure, Internet history, political economy of communication

\section{Introduction}

Over the last decades, the Internet has grown into a dominating infrastructure for communication and has significantly altered the structural conditions for communication. Often described as a convergence between formerly separate technologies, markets, and policies, these structural transformations have been subject to intense scholarly and political debate (see Bar \& Sandvig, 2008; Braman, 2004; Dwyer, 2010; Jenkins, 2001; Latzer, 2013; van Cuilenburg \& McQuail, 2003), but few studies have looked into the structural development and consequences of Internet distribution in a Nordic context. This article therefore provides a historical overview of the gradual introduction of various types of over-the-top (OTT) services in Denmark in order to analyse how the rise of Internet distribution has challenged the established institutional arrangements, and how these changes have been addressed by market actors and policy-makers. As such,

Flensburg, S. (2021). Over-the-top and under the radar: An analysis of Internet distribution and its structural consequences in Denmark. Nordicom Review, 42(1), 93-108. https://doi.org/10.2478/ nor-2021-0022 
it serves both as an historical account of the particular development in a Nordic welfare state (Syvertsen et al., 2014) and as a more general analysis of the implications that (can) follow from the gradual shift to Internet distribution.

Denmark is an interesting case for a number of reasons: first, the Internet - and digital technologies in general - were introduced early on, spread quickly, and have, over the course of just a few decades, made significant impacts on existing sectors and business models; second, despite methodological limitations (see methods section), user patterns, market structures, and regulatory practices are relatively well-documented and monitored compared to other contexts; and finally, as Internet history is often studied from an American perspective (see, e.g., Abbate, 2000; Naughton, 2016), studies conducted in other geopolitical contexts are timely and valuable.

\section{OTT as a turning point in the history of communication}

From a technological perspective, OTT refers to distribution services running in the application layer of the Internet, through, for instance, the World Wide Web. The concept is often used in relation to audiovisual streaming and video-on-demand (Kokaram et al., 2015), and sometimes includes Internet-based voice and message services (Danish Business Authority, 2017). For the purpose of this article, I define OTT-distribution as a broader phenomenon for categorising the different types of Internet services used for sending and receiving communication content that in the past was distributed through dedicated and specialised networks. This conceptual lens entails cutting across the different symbolic uses of Internet services and the sectors that in the past served as gatekeepers for various communication technologies; instead attention is focused on the ways the Internet as a common infrastructure for communication has transformed the entire media environment (Finnemann, 2005) and, thereby, the economic and political conditions surrounding mediated communication.

Standing on the shoulders of medium theory (Meyrowitz, 1994), I emphasise the importance of a technological and material perspective when studying the institutional structures and developments that follow the introduction of new media. As argued by, for instance, Innis (1991) and Eisenstein (1980), the development of new means of communication, on the one hand, reflects existing power structures and institutional arrangements. On the other hand, technological innovations can also have a transformative influence on society as they change the material foundation for communication. While technological knowledge is crucial when studying the emergence and implications of Internet distribution, it is equally important to understand the institutional background and context and not least to connect these two perspectives. This study thereby combines recent Internet infrastructure studies (Musiani et al., 2016; Sandvig, 2013) with perspectives inspired by institutional history and political economy of communication (Hardy, 2014; Mansell, 2004; Mosco, 2009). Positioned on a middle ground between technological determinism and social constructivism (Hughes, 1994; Jensen, 2013), it highlights the technological innovations, market configurations, and regulatory interventions that shape the evolution of OTT services and their structural implications. 


\section{The pre-digital regulatory regime}

Before the breakthrough of the Internet, the existing communication infrastructures had different societal functions closely tied to their technological features. As Braman (2004: 158) puts it:

Media have been distinguished from each other in the past by the number of message receivers (one, a few or many); by the nature of interactivity, if any, between sender and receiver; and by the difference between synchronicity and asynchronicity.

Bar and Sandvig (2008) further argue that the values and goals inscribed into various types of media and communication policy were closely linked to the different communication media's technological affordances and societal functions. These structural arrangements are illustrated in Figure 1, which depicts the institutional organisation of different modes of mediated communication.

Figure 1 The communication system before the Internet

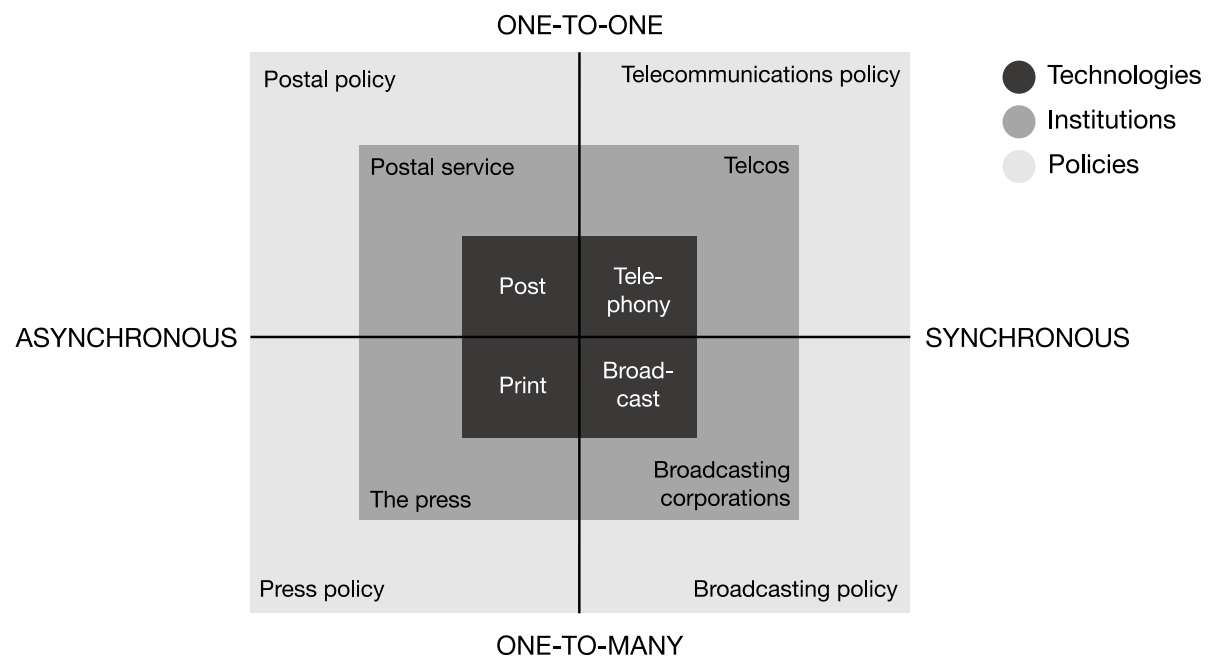

Source: Inspired by and developed on the basis of Bar and Sandvig's (2008) policy regime models.

The inner squares of Figure 1 illustrate four different communication technologies dedicated to specific types of communication: asynchronous one-to-one communication supported by post; synchronous one-to-one communication supported by telephony; asynchronous one-to-many communication supported by print; and synchronous oneto-many communication supported by broadcasting. The middle squares illustrate how each of these modes of mediated communication, and the distribution systems supporting them, were governed by particular institutions: postal service providers; telecommunications operators (telcos); the press; and broadcasting corporations. These institutions were, in turn, acting on the basis of particular logics and legislative frameworks, as illustrated by the outer squares: postal policy; telecommunications policy; press policy; and broadcasting policy. The governance structures, regulatory principles, business models, and so forth were all tied to the infrastructural and material features and com- 
municative affordances of each technology. Legacy broadcasting, for instance, utilised scarce frequencies and required significant economic and technological resources, which placed this important type of public communication in the hands of a few corporations, and legitimised rather strict regulation, monitoring, and control.

It is, however, important to note that this organisation should also be seen as a result of the social arrangements, political priorities, and economic interests prevailing when the technologies were invented and developed (Gripsrud, 2010). In Denmark - and the Nordic region in general - all parts of the historical communication system were, to varying degrees and in different ways, influenced by the Nordic welfare model of the twentieth century: The postal system was operated by a state monopoly, and universal service obligations, price regulation, and so forth were put down in national post laws; The organisation and practices of the press reflected the so-called democratic corporatist model characterised by a high degree of cooperation between political institutions and media corporations, public subsidies, and co-regulation (Hallin \& Mancini, 2004); telecommunications operators were, up until the 1990s, monopoly institutions and to a wide extent state owned and regulated in similar ways as the postal system; and finally, broadcasting was organised as a public monopoly until the 1980s, where various competing distributors as well as commercial radio and television stations entered the market, but public broadcasters continued to dominate (Lund et al., 2009).

In their book The Media Welfare State: Nordic Media in the Digital Era, Syvertsen and colleagues (2014: 2) identify four principles - or "pillars" - that characterise the structural conditions surrounding media and communication in Scandinavia: "universal services, editorial freedom, a cultural policy for the media; and last, but not least, a tendency to choose policy solutions that are consensual and durable, based on consultation with both public and private stakeholders". According to the authors, these institutional characteristics can be traced historically and continue to have a significant impact on Nordic societies: "although both principles and practices of media policy and regulation are modified and changed, such principles and practices are also to a large degree reaffirmed, sustained, and strengthened in the digital age" (Syvertsen et al., 2014: 2). Later analyses, focusing specifically on the Danish context, confirm the presence of such institutional continuity, emphasising, for instance, a political safeguarding of existing regulatory schemes and a continued welfare discourse in the political debates (Kammer, 2016; Ørsten \& Willig, 2016).

The following analysis tests and critically discusses the continued impact of welfare state logics and regulatory power by examining the structural implications of the increasing use of Internet distribution. It argues that the political system did have a significant impact on the structural conditions and developments in the media and communication sectors in the early days of digitalisation, where Internet infrastructures were, to a wide extent, developed and provided by public institutions and encouraged by comprehensive digitalisation strategies and political agreements (Flensburg, 2020). However, as the analysis shows, the gradual shift to Internet-based communication would eventually challenge the Danish welfare regime and transform the institutional logics that had successfully regulated the structural conditions for mediated communication in the twentieth century. 


\section{Methodology and source materials}

The analysis builds on textbooks and other secondary sources, market analyses and statistics, annual reports and financial statements, as well as political agreements, legislative material, reports, and other policy documents. The specific source materials were chosen because they provide information on the technological features of various types of (legacy or digital) distribution systems, business models, and market structures or political arrangements and decisions. I focus mainly on the structural developments and less on, for instance, the discursive and ideological aspects. This is not to say that the latter is unimportant or irrelevant, but rather to stress the value of discussing the findings of existing studies (focusing on discourses and ideologies) in the light of the material and structural conditions - and vice versa.

The data was collected through open databases and libraries accessed mainly digitally and through snowball sampling (where one document has referred to another). When writing the history of OTT-distribution, there is a clear discrepancy between studying the effects that the Internet has on legacy media and the structural development of purely Internet-based services. While legacy technologies and market actors are intensively monitored, corporations and communication services born with the Internet and basing their business models on digital and datafied activities continue to pass under the radar when it comes to public monitoring and regulation. At least in a Danish context, the structural conditions for Internet-based communication are highly undescribed and undocumented, leaving the researcher to rely on unauthorised or commercially produced data. In describing the developments in legacy sectors and institutions, I therefore draw on highly trustworthy sources, while the data on the use, spread, and development of digital technologies, market structures, and modes of governance are less authoritative.

When analysing the transition from legacy postal services to e-mail, I rely on yearly reports from PostNord/Post Danmark and political agreements, negotiations, and so forth that document the decline in the use of traditional letters and related challenges. The increasing use of e-mail is documented by, for instance, Eurostat, but it is more difficult to find evidence on the development in the e-mail market, as well as for the governance practices. Similarly, the number of circulated printed newspapers were in the past monitored closely, but since the growing use of Internet-based services, the monitoring of online news distribution (e.g., through social media platforms) has been less transparent. In the following analysis, I mainly use statistics on media use and advertisement revenues in order to gauge the shifting power balance in the publishing industry. The transition from traditional telephone calls and text-message services to Internet-based voice calls and instant messages raises similar methodological problems: while legacy services are monitored by telecommunications authorities, the Internet- and app-based services increasingly taking over are not officially monitored, making it difficult to assess the power structures and business models in this growing market. And finally, the transition to Internet-based television and video streaming is equally difficult to document as, for instance, the digital rating systems continue to have significant shortcomings (Lai, 2015).

Despite these methodological limitations, the importance and timeliness of the research question demands empirical enquiries to be made and methodological uncertainties to be accepted. As I discuss further in the concluding section, the lack of official sources and monitoring should also be seen as a finding in itself, with critical repercussions for research - and ultimately regulation of OTT services. 


\section{The emergence of Internet distribution}

In the following sections, I explore how and why an increasing amount of communication content is moving from specific and dedicated networks to OTT services, and I analyse the structural consequences of this for each of the four sectors listed in Figure 1. I first outline the restructuring of the upper-left corner and discuss how asynchronous oneto-one communication were among the first activities to be digitised as postal services were increasingly replaced by e-mail, and the postal system lost its former status in the communication system. I then move to the bottom-left corner and describe the development of alternative services for asynchronous, one-to-many communication and, more specifically, how web-based services challenge the traditional publishing industry. I next focus on the upper-right corner and discuss how synchronous one-to-one communication has moved online as instant messages and Internet telephony substitute SMS and traditional phone calls, challenging the conditions in the telecommunications sector. I end up discussing the most recent development, where various types of streaming services offer alternatives to legacy broadcasting by supporting synchronous one-to-many communication.

\section{From letters to e-mails}

The first digital transmission of text took place on 29 October 1969, where researchers at UCLA succeeded in transferring a simple message to colleagues at Stanford Research Institute through the ARPANET (Abbate, 2000). In the 1970s, the software and distribution technologies were further developed, turning e-mail into the "killer application" of the early Internet (Kushida, 2015: 56). The point-to-point architecture and the slow and low-capacity connections were perfect for sending and receiving textual content that typically does not take up large amounts of capacity or require stable or fast connections. The possibility of sending text from one computer network to another thereby became a driving force for the build-out of digital infrastructures, pushing the general demand for Internet connections. As such, e-mail can be seen as the first OTT service, as it provided an alternative infrastructure for the distribution of one-to-one, asynchronous communication content and gradually outperformed traditional mail.

While e-mails before 1990 were mostly used in academia, they were quickly adopted by the population at large in the 1990s and 2000s as more people got access to Internet connections (Tanenbaum \& Wetherall, 2011). In the EU, the use of e-mail has grown from being used by 44 per cent in 2004 to 80 per cent in 2019 , and in the Nordic countries alone, e-mail is now used by over 90 per cent of the population (Eurostat, n.d.). Over the same time span, the use of postal services for sending and receiving traditional letters has decreased significantly: in Denmark alone, the total number of sent letters went from 1.46 billion in 1999 (Færch, 2016) to 265 million in 2018 (Bollerslev, 2019). This development has inevitably challenged the business models and market position of companies such as PostNord, the leading postal operator in the Nordic region (and former monopoly in Denmark). In its annual report for 2019, PostNord (2020) describes how the costs for building out the infrastructure and serving the consumers are static, while the earnings from revenues are decreasing, making it difficult for the providers to deliver the services that are required by law. As a result, the company has received significant economic compensations from the 
Danish state amounting to more than DKK 1 billion in 2018 and over DKK 100 million in the first part of 2020.

While the economic challenges faced by legacy providers of asynchronous, one-toone communication services have been subject to political discussions and amendments of existing regulatory frameworks, the digital services increasingly taking over have received less attention. E-mails cannot be regulated in the same ways physical letters can, since e-mail service providers do not necessarily control, manage, and maintain the local networks used to send and receive content, but can rely on existing network service providers and pay only for the data that is sent. As a result, international market actors can enter the Danish market without building a local infrastructure, and a wide range of market actors (e.g., Facebook, Snapchat, etc.) can provide services that can substitute traditional postal services, making the market difficult to delimit, monitor, and regulate.

As in other sectors, the shift to digital distribution has resulted in a greater supply of services, and the need for state interventions and regulation to ensure universal service and supply seems somewhat outdated. The legacy postal sector has largely been transformed to a package-delivery market and has, as a result of EU's postal service directive, been liberalised (EU Commission, 2019). However, the use of e-mail also raises new policy questions that are still to be answered. Apart from the e-mail services used for communicating with public authorities (e.g., "Eboks" in Denmark), some of the most used e-mail services are supplied by large, global tech companies (see, e.g., Statista's Global Email Client Market Share; Statista, 2018). These companies dominate the digital economy, often offer their services free of charge, and collect vast amounts of data used for targeted advertising (Nield, 2019). Despite growing focus on consent and transparency regarding these data practices (as regulated, for example, by the EU General Data Protection Regulation), the very idea that the political system should have a say in, for instance, the pricing (whatever the currency), seems definitively outdated. In other words, the public service logics governing the postal system of the past have largely been replaced by a commercial governance logic that leaves state institutions with significantly less influence on the basic conditions for communicating.

\section{From print to web-based news feeds}

While e-mail was a killer application in the early days of the Internet, the introduction of the World Wide Web constitutes its public and commercial breakthrough (Naughton, 2016). Originally developed as a publishing platform for researchers to share, locate, and retrieve documents and datasets globally, the hypertext technology and link architecture enabled Internet searches and eased the navigation between different IP addresses, which could be accessed through recognisable website names. This made digitally stored content more accessible for individual users, and, simultaneously, increased the incentives of businesses and other organisations to establish themselves online. The introduction of web-based communication can thereby be seen as an important foundation for a wide range of OTT services that use websites to communicate directly with their customers, bypassing former distributors. The publishing sector - and more specifically the press - were among the first to experience both the prospects and consequences of this new mode of distribution. 
When the first private Internet connections were established, the printed press held a strong market position in Denmark, with 75 per cent of the population reading at least one newspaper on a daily basis in 1993 (Statistics Denmark, 2015). Utilising their economic and technological resources as well as existing content, brands, and customer bases, the newspapers made an early and relatively easy entrance on the emerging web-market, and news websites quickly became among the most popular (Flensburg \& Lai, 2020). While existing market structures in the beginning seemed to be sustained online, legacy publishers towards the end of the 2000s experienced a critical turning point with the emergence of new digital platforms that gradually destabilised newspaper sales, readership numbers, and ad revenues. Social media (most prominently Facebook) entered the everyday lives of Danish media users, and by 2019, 78 per cent of the adult population used social media on a daily basis (DR Media Research, 2019).

The tremendous success of social media and other digital publishing and distribution platforms have radically transformed the Danish communication system - not least the position of the press. Web-based platforms allow users as well as organisations outside the legacy media sector to produce, publish, and distribute content independently of traditional newsrooms, while at the same time being essential intermediaries that publishers depend on for distributing content, communicating with and understanding their readers, selling ads, and so forth (Nielsen \& Ganter, 2018). Through these activities, companies such as Google and Facebook gain broad, precise, and valuable information about their users that can be sold to advertisers, and the power structure of the Danish advertisement market has, over the last decades, been turned upside-down. From 1999 to 2018, Danish dailies lost a total of DKK 3.740 million in yearly ad revenues (The Agency for Culture and Palaces, 2018), and at the same time struggled to adapt their business models to a digital environment filled with (in a monetary sense) free-of-charge alternatives.

However, Danish news institutions have only in recent years acknowledged the severeness of these structural transformations. For decades, the newspapers viewed websites mainly as redistribution and marketing platforms and provided content free of charge in the hope that it would generate print subscriptions and traffic that could attract digital advertisers (Kjersgaard-Hansen, 2005). Throughout the 2000s, significant investments went into the funding of the "free newspaper wars" (Minke, 2008); all the while, the global market actors mentioned above entered the Danish market providing state-of-the-art tools for ad sales, online distribution, hosting, traffic analysis, and so forth - in other words, the infrastructure newspapers increasingly rely on. Despite the competition from and dependence on global tech companies, Danish news corporations have, until very recently, framed public service media as the main threat to a free and independent press (Søndergaard, 2014). As such, media politics have centred around national market actors and legacy media rather than addressing the fundamental challenges related to globalisation and digitalisation.

The persistent focus on national competition structures and on sustaining the original business models of print media is reflected in the policy initiatives and reforms that have been carried out over the last decades. Since 1999, the media responsibility act has included digital news outlets, but digital media must register to fall within the competence of the Press Council. This means that platforms who do not perceive themselves as news media - or do not wish to be subject to ethical control - can choose to not sign up (Blach-Ørsten et al., 2018). Similarly, as a result of the increasing use of digital news 
sites, former state support for newspaper distribution was, in 2013, replaced with "platform neutral" editorial subsidies, but the large majority of the funding continues to be allocated to legacy news media (The Agency for Culture and Palaces, n.d.). While these initiatives somewhat support the digitalisation of legacy news institutions and might ensure the existence of traditional journalistic news content, they do not guarantee the use of it - nor the willingness to pay for it. The present regulation of news distributions thus continues to reflect an increasingly historic media environment, where legacy news institutions and editorial decision-making processes controlled the dissemination of information to the public. It does not take into consideration that the material and economic conditions for news production and distribution are fundamentally transformed, that public subsidies can no longer ensure a thriving and diverse news market, and that Danish media users receive information from a multitude of sources that do not fall within the established definitions of "news media".

Though recent debates related to the Covid-19 crisis, the political situation in the US, and so forth have drawn renewed attention to the editorial responsibilities of especially social media, Internet-based publishing platforms continue to be regulated through opaque governance principles and practices. While, for instance, the EU is currently working on "tackling online disinformation" (EU Commission, 2021b), and various initiatives seek to challenge the market dominance of large tech companies, the impact of traditional welfare state regulation on how the public spread of information is organised and controlled has diminished significantly. Similar to the transition from postal services to e-mail, the distribution of public information and debate - through, for instance, social media platforms - depends on business models and revenue streams that are less transparent, monitored, and controlled than the legacy sectors responsible for these critical societal functions in the past.

\section{From telephone calls to apps}

While the early dial-up and broadband connections altered the conditions for text-based, asynchronous communication, they were less suited for synchronous communication that continued to be closely tied to traditional telecommunications services. In the early phases of digitalisation, most Danes still had a landline telephone subscription, more and more acquired cell phones and thereby mobile subscriptions, all the while the number of Internet connections was steadily growing (National IT and Telecom Agency, Denmark, 2006). Rather than challenging the existing revenue streams, offering Internet connections became a profitable ad-on to the existing business models of telecommunications providers, who could utilise and develop their infrastructures, expertise, and customer base to position themselves as Internet Service Providers (ISPs). The growing revenues enabled the telcos to further develop the infrastructure - for instance, the build-out of mobile networks and optic-fibre connections - which in turn made Internet-based services even more available and attractive.

Paradoxically, the successful penetration of the Internet and the comprehensive build-out of digital infrastructures has gradually destabilised the economic foundation for telecommunications operators. Especially the development of mobile broadband and smartphones from the mid-2000s became a crucial turning point, as the emergence of apps such as Skype, Viber, Facebook Messenger, and so forth became important 
OTT services that lowered the demand for, for instance, bundled services. Over the last decades, the number of landline subscriptions dropped from 62.8 subscriptions per 100 inhabitants in 2005 to 7.6 subscriptions per 100 inhabitants in 2019, while the use of traditional mobile voice calls has stagnated, and the number of sent SMS messages dropped from 6.6 billion in 2010 to 2.7 billion in 2019 (Danish Energy Agency, 2020). As the original business models become outdated and new (global) actors enter from other sides of the value chain (e.g., Google and Facebook not only provide some of the most-used OTT services in Denmark, but are also establishing their own backbone infrastructures), regulatory principles and practices are also challenged.

Since the mid-1990s, Danish telecommunications and ICT policy has balanced between ensuring universal access, high-quality services, and low prices on the one hand, and a market-based organisation favouring free competition and innovation on the other (Henten \& Falch, 2015). The role of state regulators (first the IT and Telecommunications Agency and later the Danish Business Authority) has been to monitor market structures closely and only intervene in case of market abuse or unfair competition. Prior to the breakthrough of smartphones and app-based OTT services, this market-based organisation was highly effective and seemed to lead to a gradual decrease of the need for regulation (Layton \& Kane, 2018). However, as a result of the economic challenges faced by legacy telecommunication operators and the growing demands for strong broadband connections, the political strategy seems to be shifting, and the government now provides funding for broadband projects (Henten \& Falch, 2015). Furthermore, the OTT services that both national regulators and the EU on various occasions have acknowledged are de facto substituting existing telecommunications services (BEREC, 2016; Danish Business Authority, 2017) are not included in market statistics and monitoring practices. As such, while market structures and commercial practices of legacy providers continue to be relatively transparent, controlled, and monitored, the OTT services and the market actors who increasingly build the Danish infrastructure and support Danes' communication activities are not. As in the other examples, the welfare principles and regulatory practices that characterised communication systems such as the Danish one in the past are thus increasingly difficult to enforce.

\section{From broadcasting to streaming}

The breakthrough of audiovisual services distributed over the Internet came rather late compared with the examples mentioned above, since the Internet architecture was not originally designed to broadcast high-capacity content to large groups of receivers simultaneously. In order for Internet-based services to take over the functions of legacy broadcasting networks, a number of adjustments had to be made (Sandvig, 2015). First, the access networks needed to be strong and fast in order to successfully transport sound and video without delays and drops in quality. Second, software for controlling the reception and display of content was gradually invented and improved, enabling, for instance, live-streaming to substitute live broadcast. Finally, local distribution networks (so-called content delivery networks, or CDNs) made it possible to store high-capacity content locally and thereby reduced the risks of network congestion.

As a result of the infrastructural limitations of the early Internet, the traditional broadcasting systems and institutions sustained their positions in the communication 
system, and the Danish television industry was in growth throughout the 2000s: various types of wired television distribution networks were established, the total number of cable-TV subscriptions grew steadily (Statistics Denmark \& National IT and Telecom Agency, Denmark, 2020), and the average daily television consumption went from 151 minutes in 2000 to 201 minutes when it peaked in 2010 (The Agency for Culture and Palaces, 2019b). The entry of Netflix to the Danish market in 2012 was a pivotal moment leading to rapid transformation of the broadcasting market and a steep decline in the daily television consumption, which fell to 142 minutes, the lowest since 1992 (The Agency for Culture and Palaces, 2019b). Over the same period, the sales of traditional TV-packages started to drop as more and more cancelled or downgraded their cable-TV subscriptions (Jørgensen, 2018), which in turn evoked bitter conflicts between distributors, production companies, and broadcasters (Leonhard, 2019). Thus, Danish consumers increasingly access audiovisual content through Internet-based streaming services, and, although the public broadcaster DR is among the most-used streaming services in Denmark, international providers such as Netflix and YouTube dominate the streaming market (DR Media Research, 2019).

This turn to Internet-based streaming raises a number of challenges to existing business models, market structures, and regulation. First, from an economic perspective, there are important and fundamental differences between legacy broadcasting and streaming: while the costs connected to broadcasting (e.g., terrestrial, cable-based, or satellite) are relatively fixed regardless of the number of receivers, the costs for streaming increases as the number of viewers grows. That is, when a user turns off the terrestrial signal and connects to a smart-TV, the terrestrial network continues to run, while the distribution system supporting streaming is activated and requires data to be sent back and forth. A provider such as DR, therefore, must maintain and finance the terrestrial network, while at the same time being charged by, for instance, their CDNprovider (in the case of DR, the American company Akamai). Commercial broadcasters and distributors also find themselves in dilemmas when confronted with changing user patterns: should they aim to protect their original business models, develop their existing products, and try to convince people to keep their television packages? Or should they invest in streaming infrastructures and go into direct competition with global actors such as Netflix, Amazon, and Disney? Or, as is the case right now, should they fight at both fronts and accept the economic consequences? Just as in the publishing sector, the foundation of the formerly profitable market for television advertisement eroded as ratings went down, global competitors entered the market, and prices for online advertising dropped (The Agency for Culture and Palaces, 2018).

The emergence of OTT services has, in other words, transformed the business models that grounded broadcasting synchronous one-to-many communication in the past, while at the same time transforming this mode of communication all together. The fact that sound and video can now be distributed from a multitude of different senders, and can be accessed and received asynchronously as well as synchronously, challenges the fundamental principles of broadcasting policy, making the very definition of audiovisual media services unclear and subject to ongoing political debate. Despite EU efforts to include streaming and video-on-demand services into existing broadcasting legislation (EU Commission, 2021a), the regulation of Internet-based audiovisual media services in Demark is limited, and the Danish radio and television council has only on one 
occasion assessed (and dismissed) a case relating to streaming (The Agency for Culture and Palaces, 2019a). Also, the public service schemes continue to follow the allocation of frequencies and transmission permissions, meaning that the markets for podcasts and streaming are only indirectly affected - when the large radio and television institutions (re-)distribute their content online. The regulation of Internet-based streaming is further challenged by the digital rating systems that complicate measurements, monitoring, and comparisons of the use of streamed content (Lai, 2015), which, in turn, challenges the ways broadcasters' performances and market shares are evaluated and controlled. Furthermore, the growing reliance on commercial and global distribution networks represents a significant, albeit unexposed, policy shift, as the underlying infrastructures supporting public service broadcasting in the past were publicly owned and run, while the systems taking over (e.g., CDNs) are provided by private, commercial market actors. These private networks raise a number of concerns relating to pricing, routing policies and agreements, and so forth that are less transparent and monitored than the distribution systems of the past (Claffy et al., 2016). All in all, as the resources for distributing audiovisual content to the broader public are no longer reserved for certain institutions (e.g., public service broadcasters), policies aimed at regulating these specific institutions no longer have the same effect on the supply of content and the conditions for accessing it.

\section{A new institutional order - conclusions and perspectives}

As mentioned in the beginning of this article, existing research often concludes that Nordic media systems like the Danish one are resilient to the challenges related to digitalisation, and that the institutional arrangements are sustained despite the structural transformations following the breakthrough of the Internet (Kammer, 2016; Ørsten \& Willig, 2016; Syvertsen et al., 2014). When studying the impact and consequences of the growing reliance on Internet distribution, it is important to not be caught up in technological determinism and neglect to take into consideration the impact of institutional structures and traditions. Looking back on the last decades of media and Internet policy, welfare traditions and logics have surely influenced the uptake of digital technologies and the responses to market disruptions. Similarly, the impact of EU liberalisation and digitalisation strategies should not be underestimated. However, the main conclusion of this article is that it is equally problematic to underestimate how the transformation of the basic material foundation for communication influences the institutional arrangements and logics that govern the use of media and communication technologies. While policy-makers might sustain a welfare state discourse and maintain established regulatory practises, the effects of these activities are not static. While legacy institutions continue to hold high political legitimacy, and efforts are made to secure their existence, their former exclusive positions in the communication system and, thereby, in the lives of individual media users, cannot be restored. And although new media and communication technologies do not fit into existing institutional frameworks, their organisation and governance do, nonetheless, influence the institutional structures that frame mediated communication.

To summarise the four analytical examples of how OTT distribution has transformed the structural conditions for communication in Denmark and how various stakeholders have responded, I briefly return to and discuss each of the four pillars of media welfare 
states suggested by Syvertsen and colleagues (2014). The first characteristic - that basic communication technologies and services are generally seen as public goods and organised as universal services - can, on the one hand, be confirmed by the continued presence of, for instance, media subsidies, public service policies, and various forms of state funding provided to ensure equal access and high functionality. On the other hand, these subsidy schemes continue to focus mainly on legacy actors and infrastructures, while the digital infrastructures and services increasingly crucial for Danes' mundane communication activities are subject to limited state regulation. The digital infrastructures are largely - and increasingly - commercially owned and controlled; routing agreements and economic arrangements are untransparent and subject to limited official monitoring. The growing use of Internet distribution is thereby de facto diminishing the role of legacy institutions and infrastructures and the effect of established policy schemes, while the challenges raised by Internet distribution are still to be fully identified and addressed.

The second characteristic - a strong presence of national institutions acting within self- and co-regulatory frameworks ensuring a freedom from direct political interference in day-to-day decision-making - can similarly be confirmed by the continued political interest in protecting national, legacy institutions and by the efforts made to amend, for instance, media liability regulation. However, as illustrated by the examples presented above, all the legacy institutions that governed mediated communication in the past have lost their former position in the communication system. Their business models are under severe pressure, making them increasingly reliant on public funding all the while they have grown heavily dependent on commercial intermediaries and third-party service providers, who act on the basis of very different logics and are not subject to the same legal requirements. As such, the actual impact of these institutions, their governance practices, and the regulatory initiatives seeking to impact their organisation and activities, has decreased significantly.

The third characteristic - a tradition for cultural policy to be extended to the media can similarly be found in the recurrent debates on the role of public service media and state authorities' (increasing) involvement in strategic and editorial decisions (Søndergaard \& Helles, 2014). There is no doubt that, in particular, legacy media continue to be seen as important cultural institutions with high societal value. Nonetheless, this pillar of the media welfare state also seems less constant if we apply a broader perspective and consider the regulation of the entire communication environment. The platforms where Danes spend more and more of their time and gain an increasing amount of information have not been included in the established media policy frameworks, and the ministry and agency of culture continue to focus on legacy media rather than the platforms and sites falling outside - and challenging the very definition of - traditional "news media".

And finally, the fourth pillar - characterised by a preference for consensual and durable policy solutions based on cooperation between stakeholders - continues to be apparent when studying official media negotiations, telecommunications agreements, and so forth, but is less evident when studying the broader organisation and regulation of the communication system. Despite growing awareness - on a national as well as EU level - of the dominant position of global tech companies, and efforts made to increase their responsibilities in terms of, for instance, content quotas, tax payments, and so forth, no effective compromises have so far been reached. Since the global market actors originate and run their businesses from other jurisdictions and are less dependent on 
small markets like the Danish one, national authorities struggle to enforce legislation, and even to establish a dialogue.

Taken together, the analysis and arguments presented above provide various contributions for further research: first and foremost, they illustrate the value of applying the OTT concept as a theoretical and analytical lens for capturing the structural implications of the rise of the Internet as a common infrastructure for communication. Focusing on the shift in distribution technologies points attention to the fundamental material transformation of the communication environment that cuts across established sectors and alters the basic conditions for business models and regulation. It also enables researchers to interpret the institutional development in a different light than previous analyses, by moving beyond the official policy initiatives or the discourses and intentions expressed by policy-makers and other stakeholders and instead considering the actual effects of legislative frameworks and regulatory interventions. In this light, the political initiatives and reforms, as well as the market actors' strategies, might be an expression of institutional inertia rather than a sign of the welfare model being resilient to the changes brought about by the Internet.

\section{References}

Abbate, J. (2000). Inventing the Internet. Cambridge, Massachusetts: MIT Press.

Bar, F., \& Sandvig, C. (2008). US communication policy after convergence. Media, Culture \& Society, 30(4), 531-550. https://doi.org/10.1177/0163443708091181

BEREC. (2016). Report on OTT services. EU. https://berec.europa.eu/eng/document_register/subject_matter/ berec/reports/5751-berec-report-on-ott-services

Blach-Ørsten, M., Hartley, J. M., \& Flensburg, S. (2018). Denmark: Voluntary accountability driven by political pressure. In T. Eberwein, S. Fengler, \& M. Karmasin (Eds.), The European handbook of media accountability (pp. 54-62). London: Routledge. https://doi.org/10.4324/9781315616353

Bollerslev, A. (2019). Danskerne sender farre breve. DR. https://www.dr.dk/ligetil/danskerne-sender-faerrebreve

Braman, S. (2004). Where has media policy gone? Defining the field in the twenty-first century. Communication Law and Policy, 9(2), 153-182. https://doi.org/10.1207/s15326926clp0902_1

Claffy, K. C., Clark, D. D., Bauer, S., \& Dhamdhere, A. D. (2016). Policy challenges in mapping Internet interdomain congestion (SSRN Scholarly Paper ID 2756868). Social Science Research Network. https:// papers.ssrn.com/abstract $=2756868$

Danish Business Authority. (2017). OTT-tjenester - set i en dansk sammenhæng [OTT services - seen in a Danish context]. https://erhvervsstyrelsen.dk/sites/default/files/2019-03/ott-rapport_januar_2017_pdf.pdf

Danish Energy Agency. (2020). Danish tele statistics, second half of 2019. Energistyrelsen. https://ens.dk/ ansvarsomraader/telepolitik/tal-paa-teleomraadet

DR Media Research. (2019). Medieudviklingen 2019. file:///Users/mnc934/Downloads/ medieudviklingen2019_0c11d1cb-2.pdf

Dwyer, T. (2010). Media Convergence. Berkshire, England: Open University Press.

Eisenstein, E. L. (1980). The printing press as an agent of change. Cambridge: Cambridge University Press.

EU Commission. (2019). Internal market, industry, entrepreneurship and SMEs: EU postal services policy. European Commission. https://ec.europa.eu/growth/sectors/postal-services/eu-postal-services-policy_en

EU Commission. (2021a). Shaping Europe's digital future: Audiovisual Media Services Directive (AVMSD). European Commission. https://ec.europa.eu/digital-single-market/en/audiovisual-media-services-directive-avmsd

EU Commission. (2021b). Shaping Europe's Digital Future: Tackling online disinformation. European Commission. https://ec.europa.eu/digital-single-market/en/tackling-online-disinformation

Eurostat. (n.d.). Individuals using the internet for sending/receiving e-mails. Retrieved October 9, 2020, from https://ec.europa.eu/eurostat/databrowser/view/tin00094/default/table?lang=en

Finnemann, N. O. (2005). Internettet i mediehistorisk perspektiv [The Internet in a media historical perspective]. Frederiksberg, Denmark: Samfundslitteratur.

Flensburg, S. (2020). Det digitale systemskifte: En historisk analyse af digitaliseringen af det danske kommunikationssystem [The digital system change: A historical analysis of the digitalisation of the Danish 
communication system] [Doctoral thesis, University of Copenhagen, Denmark]. https://static-curis.ku.dk/ portal/files/233784455/Ph.d._afhandling_2020_Flensburg.pdf

Flensburg, S., \& Lai, S. S. (2020, May 5). Networks of power: Analysing the evolution of the Danish Internet infrastructure. Internet Histories, 1-22. Advance online publication. https://doi.org/10.1080/2470147 5.2020 .1759010

Færch, E. (2016). Posten i krise: Vi sender en milliard forre breve [The post in crisis: We send a billion fewer letters]. TV 2 Nyheder [TV 2 News]. https://nyheder.tv2.dk/samfund/2016-09-23-posten-i-krise-visender-en-milliard-faerre-breve

Gripsrud, J. (2010). Mediekultur, mediesamfund [Media culture, media society]. Copenhagen: Hans Reitzel.

Hallin, D. C., \& Mancini, P. (2004). Comparing media systems: Three models of media and politics. Cambridge: Cambridge University Press. https://doi.org/10.1017/CBO9780511790867

Hardy, J. (2014). Critical political economy of the media: An introduction. London: Routledge. https://doi. org/10.4324/9780203136225

Henten, A., \& Falch, M. (2015). Denmark. In W. Lemstra, \& W. H. Melody (Eds.), The dynamics of broadband markets in Europe: Realizing the 2020 digital agenda (pp. 110-135). Cambridge: Cambridge University Press. https://doi.org/10.1017/CBO9781139683555

Hughes, T. P. (1994). Technological momentum. In M. R. Smith, \& L. Marx (Eds.), Does technology drive history? The dilemma of technological determinism (pp. 101-113). Cambridge, Massachusetts: MIT Press.

Innis, H. A. (1991). The Bias of communication (Reprinted). Toronto: University of Toronto Press.

Jenkins, H. (2001, June 1). Convergence? I diverge. MIT Technology Review. https://www.technologyreview. com/2001/06/01/235791/convergence-i-diverge/

Jensen, K. B. (2013). Definitive and sensitizing conceptualizations of mediatization. Communication Theory, 23(3), 203-222. https://doi.org/10.1111/comt.12014

Jørgensen, H. (2018, May 28). Kunderne flygter: Dansk kabel-tv bliver kvalt [Customers flee: Danish cable-TV is strangled]. Ekstra Bladet. https://ekstrabladet.dk/kup/elektronik/teknologi/kunderne-flygter-danskkabel-tv-bliver-kvalt/7165253

Kammer, A. (2016). A welfare perspective on Nordic media subsidies. Journal of Media Business Studies, 13(3), 140-152. https://doi.org/10.1080/16522354.2016.1238272

Kjersgaard-Hansen, K. (2005). Netaviser i en brydningstid [Online newspapers in a time of upheaval]. https:// journalisten.dk/netaviser-i-en-brydningstid/

Kokaram, A., Crinon, R., \& Catania, N. (2015). OTT (Over-The-Top) in 2015. SMPTE Motion Imaging Journal, 124(6), 65-68. https://doi.org/10.5594/j18597

Kushida, K. E. (2015). The politics of commoditization in global ICT industries: A political economy explanation of the rise of Apple, Google, and Industry Disruptors. Journal of Industry, Competition and Trade, 15(1), 49-67. https://doi.org/10.1007/s10842-014-0191-3

Lai, S. S. (2015). Ratings revisited. Tidsskrift for Medier, Erkendelse Og Formidling, 3(1), 5-29. https:// tidsskrift.dk/mef-journal/article/view/28700

Latzer, M. (2013). Media convergence: Handbook on the digital creative economy. https://www.elgaronline. $\mathrm{com} /$ view/edcoll/9781781004869/9781781004869.00022.xml

Layton, R., \& Kane, J. (2018). Alternative approaches to broadband policy: Lessons on deregulation from Denmark. Mercatus Working paper, 62 pages. SSRN Electronic Journal. https://doi.org/10.2139/ssrn.3191487

Leonhard, A. (2019,). Forstå tv-krigen: Yousee og Discovery står begge i store problemer efter sammenbrud [Understanding the TV War: Yousee and Discovery are both in big trouble after the crash]. FINANS. https://finans.dk/erhverv/ECE11738209/forstaa-tvkrigen-yousee-og-discovery-staar-begge-i-storeproblemer-efter-sammenbrud/

Lund, A. B., Nord, L., \& Roppen, J. (2009). Nye udfordringer for gamle medier: skandinavisk public service i det 21. århundrede [New challenges for old media: Scandinavian public service in the 21 st century]. Gothenburg: Nordicom, University of Gothenburg.

Mansell, R. (2004). Political economy, power and new media. New Media \& Society, 6(1), 96-105. https:// doi.org/10.1177/1461444804039910

Meyrowitz, J. (1994). Medium theory. In D. Crowley, \& D. Mitchell (Eds.), Communication Theory Today (pp. 50-77). Cambridge: Polity Press. https://www.academia.edu/10381784/_Medium_Theory_

Minke, K. (2008). Aviskrigen: dagblade i overlevelseskamp [The newspaper war: Dailies in survival struggle]. Copenhagen: Borgen.

Mosco, V. (2009). The political economy of communication. London: Sage. http://dx.doi. org/10.4135/9781446279946

Musiani, F., Cogburn, D. L., DeNardis, L., \& Levinson, N. S. (2016). The turn to infrastructure in Internet governance. New York: Palgrave Macmillan. https://doi.org/10.1057/9781137483591

National IT and Telecom Agency, Denmark. (2006). Tele Yearbook 2006. https://www.ft.dk/samling/20061/ almdel/uvt/bilag/254/397225.pdf 
Naughton, J. (2016). The evolution of the Internet: From military experiment to general purpose technology. Journal of Cyber Policy, 1(1), 5-28. https://doi.org/10.1080/23738871.2016.1157619

Nield, D. (2019). All the ways Google tracks you - and how to stop it. Wired. https://www.wired.com/story/ google-tracks-you-privacy/

Nielsen, R. K., \& Ganter, S. A. (2018). Dealing with digital intermediaries: A case study of the relations between publishers and platforms. New Media \& Society, 20(4), 1600-1617. https://doi. org/10.1177/1461444817701318

PostNord. (2020). Arsrapport 2019 [Annual report 2019]. https://www.postnord.dk/siteassets/pdf/finansiel-info/arsregnskabsmeddelelser/arsrapport-2019.pdf

Sandvig, C. (2013). The Internet as infrastructure: The Oxford handbook of Internet studies. https://doi. org/10.1093/oxfordhb/9780199589074.013.0005

Sandvig, C. (2015). The Internet as the anti-television: Distribution infrastructure as culture and power. In L. Parks, \& N. Starosielski (Eds.), Signal traffic (pp. 225-245). Champaign, Illinois: University of Illinois Press. https://www.jstor.org/stable/10.5406/j.ctt155jmd9.14

Statista. (2018). Global email client market share 2018. Retrieved October 9, 2020, from https://www.statista. com/statistics/265816/most-used-e-mail-service-by-market-share/

Statistics Denmark. (2015). Dagblade og tidsskrifter 2014 [Newspapers and magazines 2014]. https://www. dst.dk/Site/Dst/Udgivelser/nyt/GetPdf.aspx?cid=19097

Statistics Denmark \& National IT and Telecom Agency, Denmark. (2020). Kabel-TV abonnementer efter selskab og tilslutningstype (afsluttet) [Cable-TV subscriptions by company and type of connection (discontinued)]. Statistikbanken: Kultur og kirke [ StatBank Denmark: Culture and the church]. https:// www.statistikbanken.dk

Syvertsen, T., Enli, G., Mjøs, O. J., \& Moe, H. (2014). The media welfare state: Nordic media in the digital era. Ann Arbor, Michigan: University of Michigan Press. https://doi.org/10.2307/j.ctv65swsg

Søndergaard, H. (2014). Når en fælles fjende er den bedste ven i nøden: Dansk mediepolitik til debat [When a common enemy is the best friend in need: Danish media policy for debate]. Nordicom-Information, $36(1), 65-72$.

Søndergaard, H., \& Helles, R. (2014). Media policy and new regulatory systems in Denmark. In E. Psychogiopoulou (Ed.), Media policies revisited (pp. 41-54). London: Palgrave Macmillan. https://doi. org/10.1057/9781137337849_4

Tanenbaum, A. S., \& Wetherall, D. (2011). Computer networks (5th ed). Boston: Pearson Prentice Hall.

The Agency for Culture and Palaces. (n.d.). Tilskudsmodtagere af redaktionel produktionsstøtte [Beneficiaries of editorial production support]. Retrieved February 15, 2021, from https://slks.dk/omraader/medier/ skrevne-medier-trykteweb/redaktionel-produktionsstoette/tilskudsmodtagere/

The Agency for Culture and Palaces. (2018). Annonceomscetning 2018 [Ad revenue 2018]. Mediernes udvikling i Danmark [Media development in Denmark]. https://mediernesudvikling.slks.dk/2018/branche/ annonceomsaetning/

The Agency for Culture and Palaces. (2019a). Klage over reklame for Føtex vist på Facebook [Complaint about advertising for Føtex shown on Facebook]. https://slks.dk/omraader/medier/reklamer-i-radiotv-og-on-demand/afgoerelser-og-verserende-sager/reklameafgoerelser/afgoerelser-2018/klage-overreklame-for-foetex-vist-paa-facebook/

The Agency for Culture and Palaces. (2019b). Tv og streaming 2019 [TV and streaming 2019]. Mediernes udvikling i Danmark [Media development in Denmark]. https://mediernesudvikling.slks.dk/fileadmin/ user_upload/dokumenter/medier/Mediernes_udvikling/2019/Tv_og_streaming/PDF-filer_Tv_og_streaming/TV_2019.pdf

van Cuilenburg, J., \& McQuail, D. (2003). Media policy paradigm shifts: Towards a new communications policy paradigm. European Journal of Communication, 18(2), 181-207. https://doi. org/10.1177/0267323103018002002

Ørsten, M., \& Willig, I. (2016). Det danske mediesystem [The Danish media system]. In T. Olesen (Ed.), Medier, politik og samfund [Media, politics, and society] (pp. 13-34). Copenhagen: Hans Reitzel.

(C) 2021 Nordicom and respective authors. This is an Open Access work licensed under the terms of the Creative Commons Attribution-NonCommercial-NoDerivatives 4.0 International Public licence (CC BY-NC-ND 4.0). To view a copy of the licence, visit https://creativecommons.org/ licenses/by-nc-nd/4.0/ 